\title{
BOARD RACE GAME AS AN ALTERNATIVE STRATEGY IN TEACHING VOCABULARY
}

\begin{abstract}
Salmon J Hukom
sjhukom@yahoo.com

English Department, Pattimura University, Ambon - Maluku Indonesia

Abstract. Like other components of language in teaching, vocabulary needs special teaching strategy from teacher in order to make the students enrich the number of their vocabulary. This paper aims to discuss board race game as an alternative teaching strategy of vocabulary. Many experts and researchers have conducted studies about this game in teaching vocabulary and the results show significant improvement toward the enrichment of vocabulary after implementing board race game. The board race game has exciting steps in which they can encourage the students to become more active in teaching vocabulary. This game also presents new atmosphere in teaching and learning since it motivates the students to compete one another fairly.
\end{abstract}

Keywords: Board Race Game, Teaching Strategy, Vocabulary

\section{Introduction}

Language is a bridge of communication. The activity of communication can run smoothly if it is supported by many aspects such as knowledge of topics being discussed and knowledge of language used. The knowledge of language used in communication covers knowledge of structures, grammar, vocabulary and other aspects of language.

Vocabulary is the basic element of any language. As an essential aspect in language, vocabulay in general is very important since it helps language users to understand information in printing papers and in a form of audio. The writers can expreas their written ideas for the readers and the speakers and their partners in speaking can communicate smoothly since they have adequate numbers of vocabulary. Alqahtani (2015) stated that as languages are based on words, vocabulary is crucial in learning a language. Without vocabulary, language learners will find difficulties and confusion to convey opinions in speaking and writing and understand words in reading and listening.

In studying certain language as a foreign language like English needs extra efforts from the learners to master that language. Those extra efforts like mastering grammar and structure, having sufficient numbers of vocabulary, and practicing the language in speaking and writing.

To have adequate numbers of vocabulary, for example, students need means such as strategies to help them to improve and enrich their vocabulary. The teacher should select appropriate strategies and one of very helpful strategies is game. Game can create conducive atmosphere of teaching because it is fun. In context of 
teaching English for young learners, Halliwell (1992) argued that due to the creative language skill young learners bring into the classroom, teachers have to provide them with a communicative atmosphere where they could express themselves. Also, because the language used in any activity is unpredictable, teachers have to encourage them to actively construct language for themselves. That is why games are important and useful. Not only they are fun, but also they create the desire to communicate and create predictability.

Teaching and learning vocabulary through the conventional strategies has become boring process in EFL classes. Nowadays, games have becomea vocabulary learning strategies which are considered giving positive effect in enriching vocabularies. Some researchers also have conducted their studies toward the implementation of games in teaching and learning vocabulay. Among many games that have been introduced in their studies, board games are a kind of game that implemented and this game could give positive contribution in improving students' vocabulary enrichment. Octaviani et. $\mathrm{Al}$ (2019) in their research reported that board race games can help the students in increasing vocabulary mastery besides that game also helped the students to have good pronounciation, understand the meaning of new words and their spelling.

\section{The Essense of Vocabulary}

Pikulski and Templeton (2004) define vocabulary as "the sum of words used by, understood by, or at the command of a particular person or group.". On the hand, Hornby cited by Alqahtani (2015) said that vocabulary as the total number of words in a language; vocabulary is a list of words with their meaning.

In general, the language users express and undertsand ideas or messages through the meaning of vocabulary. In learning a foreign language, for example, vocabulary as one of language components plays an important role. It is one element that links the four basic skills like speaking, listening, reading and writing. In order to communicate well in a foreign language, students should acquire an adequate number of words and should know how to use them appropriately. In other words, vocabulary can be means to bridge ideas in communication.

In real life, it is not denied that English users become more confident and succes since they have enough vocabularies to express and understand messages in communication. For this reason, Siriwan (2013) state that language learners with vocabulary knowledge can achieve a great deal of success in their classroom, their social life, and in their continuing acquisition of the target language. Vocabulary knowledge involves all the different aspects of a word or vocabulary. Possessing vocabulary knowledge means being able to recognize the item and the system features of vocabulary that is understanding the word items (item knowledge) and the various features of word items (system knowledge) (Nation, 2001). Nation has devised a three category framework in order to examine the possession of vocabulary knowledge. They are:

1.) Word form: including the spoken form (phonological), the written form (orthographic), and the word parts (base, affixes, etc.).

2.) Word meaning: including linking form and meaning of a word, concepts and referents, and associations. 
3.) Word use: including grammatical functions, collocations, and constraint on use (register, frequency, etc)

\section{Vocabulary Learning}

Vocabulary knowledge is not limited to indicating a definition, but it is the information of a term indicating how that term fits in the world (Stahl, 2005). This claim supports an important point made by Nagy \& Scott (2000) which is how well the language users comprehend and utilize words in different mode. For instance, Schmitt (1998) differentiates between receptive and productive knowledge. He defines receptive knowledge as being capable to understand a word, and is usually related with listening and reading. While productive knowledge means being able to produce a word in accordance with speaking and writing context. That is to say that understanding language used by other people, whether spoken or written language, is quite different from producing language oneself. Thus, it is crucial to know enough words to formulate sentences, speak with a pronunciation the listener can comprehend, or write with orthography the reader can recognize in order to speak or write with the target language.

It is also significant to bear in mind that learning of words is only part of the learning of a second language.

\section{Teaching Vocabulary}

Recent research indicates that teaching vocabulary may be problematic because many teachers are not confident about the best practice in vocabulary teaching and at times do not know where to begin to form an instructional emphasis on word learning (Berne \&Blachowicz, 2008). Teaching words is a crucial aspect in learning a language as languages are based on words (Thornbury, 2002). It is almost impossible to learn a language without words; even communicationbetween human beings is based on words. Both teachers and students agree that acquisition of the vocabulary is a central factor in teaching a language (Walters, 2004). Teaching vocabulary is one of the most discussed parts of teaching English as a foreign language. When the teaching and learning process takes place, problems would appear to the teachers. They have problems of how to teach students in order to gain satisfying results. The teacher should prepare and find out the appropriate techniques, which will be implemented to the students. A good teacher should prepare himself or herself with various and up-todate techniques. Teachers need to be able to master thematerial in order to be understood by students, and make them interested and happy in the teaching and learning process in the classroom.

The teachers should be concerned that teaching vocabulary is something newand different from student's native language. They also have to take into account that teaching English for young learners is different from adults. The teachers have to know the characteristics of his/her learners. They moreover need to prepare good techniques and suitable material in order to gain the target of language teaching. 


\section{Games}

Many practitioners of education define game in different point of view. Wright, Betteridge, and Buckby (1994) said that the word game means an activity which is entertaining and engaging, often channging, and an activity in which the learners play and usually interact with others.

In context of language, Crandall (1998) said that language games are not just time fillers or ice-breakers. They can motivate, and encourage students to discover learning and solve problems. They give the opportunity to learners to learn to use language in a meaningful way, as well as they help teachers to understand the students' needs ( cited in Khonmohammad, Gorijian, and Eskandari, 2014).

Therefore, games do not only help children learn vocabulary or grammar but also develop learners' social, communicative skills. Their sense of fair play encourages and increases cooperation. Games can help the teacher create useful and meaningful contexts for learning new vocabulary, (Cameron, 2001).

\section{Advantage of Using language Games}

Using games in teaching language has some benefits as folow

- Games Motivate Learners

Harmer (1991) says that Games are very motivating since they are entertaining, attractive and at the same time challenging. The activities in a game get all the students to move around, activate their mental competency and motivate neural networks; thus motivating learners in learning and retention. At that time, students who are shy also attend the activities with fun, forgetting their shyness and fear.

- Games Promote Learners' Interaction

As reported by Jacobs Liu (1996), interaction involves the nature of classroom pedagogy and classroom behaviour. Pair or group work is one of the major ways to enhance students' interaction. Many games can be carried out in pairs or in small groups. In that way, they provide a setting for students to build up their skills in working with others such as the skill of communication.

- Games Improve Learners' Language Acquisition

C. Riedle (2008) emphasizes the advantage of games in improving learners' achievements: "We are teaching a new generation of students, which requires unconventional teaching strategies be put into practice in the classroom. And when schools use the games, the student benefits speak for themselves and a great desire to learn and higher test score. ". In the same way of thought, games can stimulate and give confidence to students to participate in the activity since logically they want to beat the other teams. Apart from having fun, students learn and acquire new language at the same time. Students start to recognize that they have to utilize the language if they want others to understand what they are saying (Schultz \& Fisher, 1988).

\section{Board Race Game}


A board game is a game that when you play it you throw the dice in the counters and you can step forward based to dice. A board game is a game that involves counters or pieces moved or placed a pre-marked surface or board, according to set of rules. Board race game is fun game that is classified under the language board games category. It is used for revising vocabulary, whether it is words from the lesson you have just taught or words from a lesson you taught last week. It can also be used at the start of the class to get students active. Board race game is one of the developments of board game as a common game which can be played by using board, table, or floor. Board race game is a fun way for students to practice their English while enjoying some competition (Kusumawati, 2017)

\section{Steps in Applying Board Race Games in Teaching Vocabulary}

Board Race Game is a fun way to get your class up and out of their seats. The activity can be used with young students as well as with adults, depending on your classroom size. All you need are two markers, free space to move in the class and a board to write on.

The goal of a board race game is to have two people "race" from one end of the classroom to the board at the other end of the classroom and write the answer to a question on the board. The first person to finish writing the correct answer scores a point. The game allows you to test the students on a variety of topics while getting them fully engaged in the activity with some friendly "athletic" competition. Surprisingly, you may find adult students like it even more than the kids do.

Lander (2018) suggests the following steps of applying Board games in teaching vocabulary:

a. Split the class into two teams and give each team a colored marker.

b. If you have a very large class, it may be better to split the students into teams of 3 or 4.

c. Draw a line down the middle of the board and write a topic at the top.

d. The students must then write as many words as you require related to the topic in the form of a relay race.

e. Each team wins one point for each correct word. Any words that are unreadable or misspelled are not counted.

\section{Conclusion and Suggestion \\ Conclusion}

Based on the discussion above, those effective strategies will provide the teachers to use one of possible strategies in their teaching. The teacher can use them in order to help or guide the learners to have much vocabulary. Having much vocabulary will help the learners to participate in all classroom activities that need English. Board race game can be an alternative teaching strategy of vocabulary and it has clear steps of its teaching implementation. That game also can help the students enriching their vocabulary mastery besides it also can motivate the students to become active learners in class. 
Since the goal of teaching vocabulary to students is to mediate them to have much vocabulary, it is important to the teachers to select effective strategies in their teaching activities. Due to this way, the successful of strategy choice to be used will influence their success in teaching.

\section{References}

Alqahtani. 2015. The importance of vocabulary in language learning and how to be taught. International Journal of Teaching and Education, III(3), pp. 21 -34 .

Berne,J.I.\&Blachowicz,C.L.Z.(2008).WhatReadingTeachersSayAboutVocabulary Instruction: Voices From the Classroom.TheReadingTeacher 62 (4):314-323. https://www.researchgate.net/publication/228626576 What_Reading_Teachers_Say_About_Vocabulary_Instruction_Voic es_From_the_Classroom

Cameron, L. 2001. Teaching languages to young learners. Cambridge: Cambridge University Press

Crandall, J. 1998. Collaborate and cooporate: Teacher education for integrating language and contentinstruction. English Teaching Forum, 36 (1).

Halliwell, S. 1992. Teaching English in the Primary Classroom. New York: Longman.

Kusumawati,FitriPalupi.(2017).Boardracetobooststudents'vocabularymastery.Pro ceedings of the 1st INACELT(International Conference on English Language Teaching), 113-20.http://digilib.iainpalangkaraya.ac.id 1948/1/11.\%20Fitri\%20Palupi\%20Kusumawati\%20113-120.pdf

Harmer, Jeremy. 1991. The Practice of English Language Teaching New Edition. New York: Longman

Jacobs, G. M., \& Kline, L. K. (1996). Integrating language functions and collaborative skills in the second language classroom. TESL Reporter, 29, 21-33.

Lander,Emma. (2013). 10 Best ESL Games for English Teachers Abroad. https://www.gooverseas.com/blog/10-best-games-esl-teachers

Nagy, W. E., \& Scott, J. A. (2000). Vocabulary processes. In M. L. Kamil, P. Mosenthal, P. D. Pearson, \& R. Barr (Eds.), Handbook of reading research (Vol. 3, pp. 269-284). Mahwah, NJ: Erlbaum.

Nation, I.S.P. (2001). Learning Vocabulary in Another Language. Cambridge: Cambridge University Press.

Octaviani, Risa, et. al. 2019. Applying Board Race Game to Increase Students' Vocabulary Mastery in Uttayan Suksa Krabi School, Thailand. Journal of English Education Studies, Vol. 2, No. 2. 
Pikulski,J.J.\&Templeton,Shane.(2004).TeachingandDevelopingVocabulary:Keyto Long-TermReadingSuccess.HoughtonMifflinCompany, 1-15.

Riedle, C.. (2008). Web 2.0: helping reinvent education. Available at http://www.thejournal.com/articles/21907.

Schmitt, N. (1998). Tracking the Incremental acquisi- tion of second language vocabulary: A longitudi- nal study. Language Learning, 48, 281-317

Schultz, M. and A. Fisher. 1988. Interacting in the Language Classroom. Games for All Reasons. Massachusetts: Addison-Wesley Publishing Company.

Siriwan,Mayuree.(2013). 'English Vocabulary Learning Strategies Employed By Rajabhat University Students"'. Technology Faculty. Surananee University

Stahl, S. (2005). Vocabulary Development. Newton Upper Falls, MA: Brookline Books.

Thornbury,Scott.How to Teach Vocabulary. Bluestone Press, Charlbury,Oxfordshire, UK.90 and 159, www.longman.com

Walters,J.M.(2004)'Teachingtheuseofcontexttoinfermeaning:Alongitudinalsurvey ofL1 andL2vocabularyresearch'.LanguageTeaching,37(4),pp.243-252

Wright, Betteridge, and Buckby. 1994. Games for language Learning. Cambridge: Cambridge University Pres S. 